\title{
Pendidikan Islam dalam Masyarakat Madani Indonesia
}

\author{
Irfan Charis \\ MTs Negeri Andong, Kec. Andong Kab. Boyolali \\ Email: irfancharis@yahoo.co.id \\ Mohamad Nuryansah \\ UIN Walisongo \\ m_nuryansah@yahoo.com \\ DOI: 10.18326/mudarrisa.v7i2. 229-258
}

\begin{abstract}
Abstrak
Tulisan ini bertujuan untuk memetakan konsep, gagasan dan pola pendidikan Islam dalam masyarakat madani di Indonesia, dengan berpijak pada konsep pendidikan dan masyarakat madani dari aspek kesejarahan dan kenabian untuk memetakan konsep pendidikan Islam pada masyarakat madani Indonesia pada konteks kekinian dan masa yang akan datang. Penelitian ini menggunakan metode diskriptif analitis dengan mengkaji referensi yang bersumber dari perpustakaan. Dalam penelitian ini didapatkan kesimpulan bahwa masyarakat madani Indonesia mengacu kepada konsep masyarakat madaniyah yang dikembangkan oleh Rasulullah, yakni masyarakat yang memiliki keadaban demokrasi, bertakwa kepada Allah SWT, yang seimbang antara dimensi fikir (iptek) dan dimensi dzikir (imtaq), dan mampu menyelaraskan dimensi Abdun, sebagai makhluk Allah yang tanpa daya dan dimensi Khalifah, sebagai pemimpin di muka bumi. Sehingga melahirkan sosok manusia yang dalam istilah al-Quran disebut sebagai Ulul Albab. Berangkat dari terbentuknya pribadi-pribadi yang Ulul Albab tersebut maka akan terbentuk sebuah komunitas yang dikenal dengan masyarakat madani Indonesia.
\end{abstract}


This paper aims to map concepts, ideas and patterns of Islamic education in civil society in Indonesia, with rests on the concept of education and civil society from the historical aspect and the prophetic to map the concept of Islamic education in Indonesia's civil society in the context of the present and future. This research uses descriptive analytical method to assess references source from the library. It was concluded Indonesian civil society refers to the concept of Madaniyah society developed by the Prophet, the people who have the civility of democracy, fear Allah SWT, which is balanced between the fikr dimension (Science and Technology) and the dhikr dimension (imtaq), and able to harmonize the abdun dimension, as a creature of God is without power and the dimensions of the Caliph, as a leader on earth. It will create the human figure in terms of the Koran referred to as Ulul Albab. Departing from the formation of Ulul Albab, it will form a community known by the Indonesian civil society.

Kata kunci: Pendidikan, Islam, Madani.

\section{Pendahuluan}

Bangsa Indonesia yang hampir dalam satu dasawarsa sejak hantaman krisis moneter di tahun 1997, terus-menetus harus berhadapan dengan krisis politik, keamanan, sosial, budaya dan yang paling mutakhir ancaman terorisme global. Keterpurukan bangsa ini dalam multikrisis tersebut menurut Misbah Shoim adalah buah dari penumpukan AnomaliAnomali dalam sistem sosialnya (Harris, 1987: 16).

Sejak berakhirnya era Orde Baru, Indonesia sebenarnya sudah mengalami beberapa kali pergantian pemerintahan, namun situasi tak kunjung membaik. Penyelewengan-penyelewengan yang terjadi selalu direvisi dengan kesalahan yang hampir sama, sehingga menghasilkan krisis yang terus berulang. 
Masyarakat Indonesia dalam masa transisi tersebut sebuah akan kehilangan norma lama yang selama ini telah menjadi pegangan dalam sstem sosialnya. Namun norma baru sebagai penggantinya belum juga ditemukan. Akibatnya dapat ditebak, masyarakat menjadi sering mengalami disorientasi, dan krisi eksistensial yang bermuara pada budaya anarki anggota-anggotanya (Harris, 1987: 4).

Tatanan suatu bangsa dengan kata lain yang ideal hanya bisa tercipta melalui pemerintahan yang kuat dan terkonsolidasinya masyarakat madani (civil society) yang memposisikan dirinya sebagai penyeimbang negara. Jadi, persoalan mendesak yang dihadapi bangsa Indonesia adalah penataan kembali sistem kelembagaan politik, publik, dan sosial kemasyarakatan. Penataan ini harus dibarengi pula dengan pemahaman terhadap pandangan dunia (world-view) terhadap nilai-nilai religius, etika, dan moral dalam diri setiap warga negara.

Proses memahami dan menentukan sumber serta vasilidasi pandangan-pandangan sosial politik yang relevan dengan agenda reformasi sekarang ini tentu harus diawali dengan mendalami lebih jauh apa itu pengertian prinsipil tentang masyarakat madani. Bukanlah suatu kebetulan bahwa wujud nyata masyarakat madani tersebut mulai dikenal masyarakat dari hijrah Rasulullah dari Makkah ke Madinah 13 tahun setelah Nabi Muhammad membangun landasan tauhid sebagai fondasi dasar masyarakat (Komunitas Mekkah) menuju ke Yastrib dan mengubah nama menjadi kota Madinah yang diambil dari kata Madaniyah yang berarti peradaban (Azra, 1999: 3). 
Sistem sosial madani yang dikembangkan Nabi Muhammad SAW tersebut memiliki beberapa ciri unggul, yakni kesetaraan, istiqomah, mengutamakan partisipasi, dan demokrasi dengan dilandasi keimanan danketaqwaan kepada Allah. Esensi ciri unggul tetap relevan dalam konteks waktu dan tempat berbeda, sehingga pada dasarnya prinsip itu layak diterapkan apalagi di Indonesia yang mayoritas berpenduduk muslim tanpa harus mengusik kepentingan dan keyakinan kelompok monoritas. Mengenai hal yang terakhir ini Nabi Muhammad SAW telah memberi contoh yang tepat, bagaimana sebaiknya memperlakukan kelompok minoritas ini. Akan tetapi harus diakui,membangun sebuah masyarakat madani yang berperadaban, maju dan bermartabat dalam ikatan persamaan dan persaudaraan sejati tersebut memerlukan kerangkan dan pendekatan yang lebih evolusioner daripada revolusioner. Pada saat yang sama kerangka dan pendekatan ini secara implisit menawarkan ongkos sosial minimal sebaliknya pendekatan revolusioner dalam masyarakat madani, tidak saja akan meminta biaya sosial (social cost) mahal, tetapi bahkan dapat menghancurkan ketertiban dan keteraturan masyarakat yang merupakan esensi masyarakat madani itu sendiri (Raharjo, 1999: 146). Dengan demikian maka civil society menjadi tepat untuk diterjemahkan sebagai "masyarakat madani”, yang mengandung tiga hal yakni, agama, peradaban dan masyarakat.

Dalam perspektif Islam, masyarakat madani lebih mengacu kepada penciptaan peradaban. Dimana kata al-Din yang pada umumnya bermakna agama, bisa ditarik pada makna tamaddun, atau peradaan. Keduanya menyatu dalam makna kata al-Madinah yang berarti kota. 
Berbeda dengan kata al-Qaryah atau al-Balad, yang juga berarti kota yang sering juga sebagai makna sebuah negeri. Bedanya al-Madinah mempunyai muatan peradaban dan kebudayaan (Harris, 1987: 11).

Untuk mewujudkan sistem sosial masyarakat madaniyah di Indonesia, tentu harus diawali dengan membangun kualitas masyarakat di dalamnya. Salah satu upayanya adalah dengan melalui pendidikan. Telah menjadi kesepatakan umum bahwa pendidikan adalah rancangan kegiatan yang paling banyak berpengaruh terhadap perubahan perilaku seseorang dan suatu masyarakat. Sebagaimana apa yang pernah dikemukakan oleh Jalaluddin Rahmat bahwasannya perubahan sosial hanya memungkinkan terjadi manakala telah didahului oleh perubahan pola pikir masyarakat. Pendidikan merupakan model rekayasa sosial yang paling efektif untuk menyiapkan suatu bentuk masyarakat masa depan.

Pendidikan menjadi mutlak diperlukan dalam rangka untuk menganalisa dan membentuk manusia sebagai individu maupun sebagai masyarakat (Busyairi dan Sahil, 1987: 119). Sebagai individu, pendidikan menfungsikan potensi-potesi yang terdalam dan tersembunyi pada individu. Bagaikan lautan yang kaya akan mutiara dan ikan, tanpa usaha manusia barang-barang tersebut tetap akan menjadi barang yang asing dan kurang bermanfaat. Hanya dengan usaha manusia mutiara dan ikan-ikan tersebut dapat dijadikan sumber kehidupan, begitu pula potensi manusia.

Potensi akal bila diarahkan dan dikembangkan akan mampu melahirkan kemahiran berbahasa, menghitung, mengingat, berfikir dan 
daya cipta dan lain-lainnya yang dapat menghantarkan manusia ke taraf kehidupan yang sebelumnya masih merupakan sebuah mimpi. Dari manusia sebagai individu inilah setelah melalui proses pendidikan diharapkan akan melahirkan sebuah komunitas masyarakat yang dicitacitakan.

Pendidikan Islam dalam hal ini sistem nilai dan budaya yang pada akhirnya melahirkan peradaban dituntut untuk mampu menjawab persoalan-persoalan bangsa sebagaimana telah disebutkan di muka. Komitmen itu muncul berangkat dari sebuah komitmen untuk menciptakan peradaban bangsa Indonesia ke depan.

\section{Metode Penelitian}

Penelitian ini merupakan penelitian jenis kepustakaan (library research). Penelitian kepustakaan adalah penelitian yang dilakukan dengan cara mengumpulkan data, informasi, dan berbagai macam datadata lainnya yang terdapat dalam kepustakaan (Subagyo, 1991: 109). Dengan mengutarakan jenis penelitian ini, fokus dan langkah-langkah yang akan dalam penelitian ini menjadi semakin jelas. Mengenai sumber data, karena tulisan ini sifatnya adalah kajian pustaka, maka obyek yang dapat dijadikan sumber dibagi menjadi dua, yaitu primer dan sekunder. Data primer adalah adalah buku, jurnal, buletin dan karya ilmiah yang berkaitan dengan masyarakat madani (Saukan, 2000: 29). Sedangkan data sekunder adalah buku buku masih dianggap relevan dengan kajian penelitian (Arikunto, 1993: 131). 
Pendekatan yang digunakan dalam penelitian ini adalah pendekatan filosofis. Pendekatan filosofis digunakan untuk merumuskan secara jelas hakekat yang mendasari konsep-konsep pemikiran (Bakker dan Zubair, 1990: 92). Lebih lanjut pendekatan filosofis dalam penelitian ini digunakan untuk mengkaji secara mendalam beberapa problem krusial yang dihadapi pesantren. Sementara teknik pengumpulan datanya menggunakan teknik dokumentasi. Teknik dokumentasi adalah metode pengumpulan data yang dilakukan dengan cara mencari data tentang variabel penelitian dari berbagai macam dokumentasi, baik yang berupa catatan, transkip, buku, surat kabar, majalah, jurnal, dan lain sebagainya (Arikunto, 1980: 62). Untuk mengarahkan keakuratan dan ketepatan terhadap data yang diteliti, metode analisa yang digunakan yaitu content analysis.

Metode content analysis merupakan sebuah analisis terhadap kandungan isi yang tidak akan lepas dari interpretasi sebuah karya. Secara metodologis, analisis ini mencoba menawarkan asumsi-asumsi epistemologis terhadap pemahaman yang tidak hanya berkutat pada analisa teks tetapi juga menekankan pada konteks yang melingkupinya serta kontekstualisasinya dalam masa yang berbeda (Stempel, 1983: 3).

\section{Pembahasan}

\section{Konsep Masyarakat Madani Indonesia}

\section{Telaah Historis Masyarakat Madani}

Masyarakat madani, yang merupakan kata lain dari masyarakat sipil (civil society), sangat sering disebut sejak kekuatanotoriter orde baru 
tumbang selang beberapa tahun yang lalu. Kemunculan wacana masyarakat madani tersebut merupakan refleksi dari keinginanuntuk membuat suatu sistem sosial yang baru, yang dianggap akan membawa perubahan yang lebih baik dalam kehidupan masyarakat bangsa Indonesia.

Penulis mengakui tentu saja masih saja terdapat sejumlah perbedaan konsepsional dan praktikal menyangkut istilah masyarakat madani tersebut. Tetapi suatu hal jelas, bahwa dalam wacana lebih mutakhir mengenai konsep masyarakat madani terdapat kesepakatan bahwa masyarakat madani tidak lagi diperhadapkan secara oposional dengan negara (state). Dalam wacana paling akhir, masyarakat madani bukanlah alternatif dari negara melainkan sisi lain dari koin yang sama. Sisi satunya adalah negara yang sangat penting dalam pembentukan masyarakat yang memiliki keadaban demokratis.

Sebenarnya pengertian "masyarakat madani” itu mengacu kepada konsep civil society yang muncul kembali dalam diskurus akademis pada dasawarsa 90-an. Secara harfiah civil society itu sendiri adalah terjemahan latin dari civils sovietas, yang mula-mula dipakai oleh Cicero (106-43 SM.) seorang orator dan pujangga Roma yang hidup dalam abad pertama sebelum Kristus yang pengertiannya mengacu kepada gejala budaya perorangan dan masyarakat (Raharjo, 1999:137). Civil society disebutnya sebagai sebuah masyarakat politik yang memiliki kode hukum sebagai dasar pengaturan hidup, adanya hukum yang mengatur pergaulan antar individu menandai keberadaan suatu jenis masyarakat tersendiri. Pengertian ini erat kaitannya bahkan merupakan bagian dari 
konsep tentang bangsa atau warga Romawi yang hidup di kota-kota yang memiliki kode hukum yang merupakan ciri dari masyaraakt atau komunitas politik yang beradab.

Istilah masyarakat madani pertama kali dikenalkan dalam ceramah perdana menteri Malisia Anwar Ibrahim dalam festival Istiqlal 1995. Disini Dawam Raharjo memamandang agama sebagai sumber, peradaban adalah prosesnya, dan masyarakat adalah hasilnya. Dengan demikian maka civil society diterjemahkan sebagai masyarakat madani yang mengandung tiga hal, yakni agama, peradaban dan masyarakat (Raharjo, 1999: 146).

Dalam perspektif Islam, masyarakat madani lebih mengacu kepada penciptaan peradaban. Dimana kata al-Din yang pada umumnya bermakna agama, bisa ditarik pada makna tamaddun, atau peradaban. Keduanya menyatyu dalam makna kata al-Madinah yang berarti kota. Berbeda dengan kata al-Qoryah atau al-Balad, yang juga berarti kota yang sering juga sebagai makna sebuah negeri. Bedanya al-Madinah mempunyai muatan peradaban dan kebudayaan (Harris, 2003:11).

Bukanlah suatu kebetulab bahwa wujud nyata masyarakat madani mulai dikenal dari hijrah Rasulullah dari Makah ke Madinah 13 tahun setelah Nabi Muhammad membangun landasan tauhid. Hal tersebut sebagai fondasi dasar masyarakat (Komunitas Mekkah) menuju ke Yastrib dan mengubah nama menjadi kota Madinah yang diambil dari kata Madaniyah yang berarti peradaban. Kiranya menjadi penting secara sekilas memahami struktur dan karakter sosial politik di dua kota itu sangat dipengaruhi unsur kesukaan, serta sama sekali tidak memiliki 
pengalaman tentang suatu negara atau organisasi pemerintahan. Meskipun demikian, Mekkah, saat kelahiran Nabi SAW, merupakan pusat perdagangan yang kuat, yang telah mempunyai semacam konstitusi perdagangan dan dewan sesepuh, yang disebut Mala'.

Sedangkan situasi di Madinah sebelum Islam sama sekali berbeda dari Mekkah. Di kota ini terdapat lima suku yang saling berperang. Tiga suku merupakan Yahudi yakni Bani Nadir, Bani Qoynuqa' dan Bani Qurayza. Dan dua lagi suku Arab yakni suku Aws dan Khazraj. Suku-suku Yahudi menguasai wilayah yang luas dari perkebunan kurma dan jgja menguasai beberapa krajinan tangan, sementara suku-suku Arab mengedalikan tanah pertanian mereka sebagai sumber utama, suku Aws dan Khazraj saling berperang dalam waktu yang sangat penjang, dan suku-suku Yahudi juga bermusuhan satu sama lain, meskipun mereka saling mendukung ketika berhadapan dengan suku-suku Arab.

Kebutuhan akan pemimpin yang bijaksana, masyarakat Madinah mengundang Nabi SAW ke kotanya. Mereka tahu bahwa Nabi SAW banyak mendapat ancaman di Mekkah. Selama dua tahun lamanya dilakukan perundingan secara seksama,dan masuknya sebagian besar (tidak semua) penduduk dari dua suku Arab kepada Islam, Nabi SAW menerima undangan mereka untuk berimigrasi ke kota tersebut. Makkah pada masa kenabian adalah kota yang diperintah oleh elit yang terdiri dari oligarki orang-orang yang kaya dan para kepala suku. Pada tahun 662, tahun kenabian yang ke-13, Rasulullah atas undangan penduduk 
Madinah beserta sekitar 75 orang pengikutnya pindah ke Yatsrib. Yatsrib adalah sebuah daerah pertanian tetapi masyarakatnya lebih pluralis.

Yatsrib baru menjadi sebuah kota setelah dilakukan perjanjian antara Muhammad dengan penduduk Madinah dari berbagai golongan itu. Perjanjian itu dapat disebut sebagai suatu social society oleh para orientalis (Sahid, 2005). Itulah sebabnya maka perjanjian tersebut adalam konteks teori politik disebut sebagai Piagam Madinah atau konstitusi Madinah, karena di dalamnya memang terdapat pasal-pasal yang menjadi dasar hukum sebuah negara, yakni negara kota yang kemudian disebut Madinah, lengkapnya al-Madinah al Munawarah artinya Kota nan bercahaya (Raharjo, 1999: 137).

Inti dari konstitusi Madinah yang sekaligus juga merupakan kontrak sosial dan perjanjian kemasyarakatan itu menegaskan, pertama, pengakuan bahwa mereka merupakan satu kesatuan sosial yang disebut al-ummah (umat). Kedua, ereka tunduk atau berorientasi pada nilai-nilai luhur yang disebut al-khair atau kebajikan. Nilai-nilai itu adalah persatuan, keadilan, perdamaian, kesamaan,dan kebebasan. Ketiga, mekanisme itu untuk menegakkan yang baik (al-ma'ruf) dan mencegah yang buruk (al-munkar). Beberapa kebaikan yang ditegakkan itu antara lain adalah perlindungan terhadap negara, terhadap harta dan jiwa, kebebasan, beragama, keamanan, kepastian hukum dan musyawarah. Sedangkan kejelekan yang harus dicegah adalah kekacauan, kezaliman, pengerusakan, pertikaian, dan agresi dari luar. Dalam perjanjian itu ditetapkan pula bahwa selain setiap masalah harus diselesaikan melalui proses musyawarah, namun jika tetap terjadi pertikain antar kabilah yang 
tak dapat diselesaikan, maka instansi terakhir harus diserahkan kepada kebijaksanaan Muhammad SAW (Raharjo, 1999: 153).

Perjanjian tersebut (yang berisi salah satunya adalah kesepakatan untuk membentuk satu umah di Madinah) adalah awal dari suatu proses. Ketika keberagamaan masyarakat yang dapat memicu sebuah konflik tersebut sepakat untuk tunduk kepada suatu kedaulatan tertentu yakni ummah dan menerima berbagai jenis perlindungan yang disepakati dari kedaulatan itu maka telah terjadi apa yang disebut perjanjian kemasyarakatan atau social contract.

Disepakatinya perjanjian di atas maka telah terbentuk suatu umat atau masyarakat. Para orientalis menyebutnya sebagai negara (state). Memang disini, negara dan masyarakat merupakan dua sisi mata uang yang sama. Agaknya, demikian visi al-Quran mengenai agama dan masyarakat.walaupun rumusan perjanjian di atas tidak secara eksplisit dicantumkan dalam al-Quran, karena bukan wahyu melainkan perjanjian yang dilakukan oleh Rasulullah selaku pemimpin masyarakat, tetapi kita bisa mendapatkan dasar hukumnya dari al-Quran. Bahkan al-Quran menyempurnakan ketentuan-ketentuan hukum itu secara kuantitatif maupun kualitatif. Tindakan Rasulullah tersebut dikukuhkan dengan perintah oleh Allah SWT melalui al-Quran agar Nabi membentuk suatu komunitas yang jelas visi dan misinya.

Nabi Muhammad memberikan teladan ke arah pembentukan masyarakat yang berperadaban terebut. Setelah perjuangan di kota Makkah tidak menunjukkan hasil yang berarti, Allah telah menunjuk sebuah kota kecil, yang selanjutnya kita kenal dengan Madinah, untuk 
dijadikan basis perjuangan menuju masyarakat peradaban yang dicitacitakan. Di kota itu Nabi meletakkan dasar-dasar masyarakat madani yakni kebebasan. Untuk meraih kebebasan, khusunya di bidang agama, ekonomi, sosial dan politik, Nabi diijinkan untuk memperkuat diri dengan membangun kekuatan bersenjata untuk melawan musuh peradaban.

Hasil dari proses itu dalam sepuluh tahun, beliau berhasil membangun sebuah tatanan masyarakat yang berkeadilan, terbuka dan demokratis dengan dilandasi ketaqwaan dan ketaatan kepada ajaran Islam. Salah satu yang utama dalam tatanan masyarakat ini adalah pada penekanan pila komunikasi yang menyandarkan diri pada konsep egalitarian pada tataran horizontal dan konsep ketakwaan pada tataran vertikal (Sahid, 2005).

Berdasarkan pendapat di atas, dapat disimpulkan bahwa masyarakat madani pada prinsipnya memiliki makna ganda yaitu demokrasi, tranparansi, toleransi, potensi, aspirasi, motivasi, partisipasi, konsistensi, komparasi, koordinasi, simplifikasi, sinkronisasi, integrasi, emansipasi, dan hak asasi, namun yang paling dominan adalah masyarakat yang demokratis. Perbedaan yang tampak jelas adalah civil society tidak mengaitkan prinsip tatanannya pada agama tertentu, sedangkan masyarakat madani jelas mengacu pada agama Islam yang dibawa Nabi Muhammad SAW.

Konsep masyarakat madani menurut Islam adalah bangunan politik yang demokratis, pertisipatoris, menghormati dan menghargai publik seperti kebebasan hak asasi, partisipasi, keadilan sosial, 
menjunjung tinggi etika dan moralitas, dan lain sebagainya. Dengan mengetahui makna madani, maka istilah masyarakat madani secara mudah dapat difahami sebagai masyarakat yang beradab, masyarakat sipil, dan masyarakat yang tinggal di suatu kota atau berfaham masyarakat kota yang pluralistik.

\section{Karakteristik Masyarakat Madani}

Penyebutan karakteristik masyarakat madani disini dimaksudkan untuk menjelaskan bahwa dalam merealisasikan wacana masyarakat madani diperlukan prasyarat-prasyarat yang menjadi nilai-nilai universal dalam penegakan masyarakat madani, prasyarat ini tidak bisa dipisahkan satu sama lainnya atau hanya mengambil salah satunya saja. Melainkan merupakan satu kesatuan yang integral yang menjadi dasar bagi eksistensi masyarakat madani. Karakteristik tersebut diantaranya adalah adanya free public sphere, demokratis, toleransi, pluralisme,keadilan sosial, dan berkeadaban (Rosyada, 2003: 247).

Adapun sistem sosial madani menurut Nabi Muhammad SAW, maka ditemukan ciri unggul, yakni kesetaraan, istiqomah, mengutamakan partisipasi, dan demokratisasi (Rosyada, 2003: 250). Konsep tersebut dapat diaplikasikan di Indonesia tanpa mengusik kepentingan dankeyakinan kelompok minoritas. Mengenai hal yang terakhir ini Nabi SAW telah memberi contoh yang tepat, bagaimana sebaiknya memperlakukan kelompok minoritas ini.

Berdasarkan kajian di atas masyarakat madani pada dasarnya adalah sebuah komunitas dimana keadilan dan kesetaraan menjadi 
fundamennya. Muara dari pada itu adalah pada demokratisasi, yang dibentuk sebagai akibat adanya pertisipasi nyata anggota kelompok masyarakat. Sementara hukum diposisikan sebagai satu-satunya alat pengendalian dan pengawasan perilaku masyarakat. Dari definisi itu maka karakteristik masyarkat madani, adalah demokratisasi, partisipasi sosial, dan supremasi hukum dalam masyarakat.

Dengan demikian semakin jelas bahwa masyarakat madani merupakan bentuk sinergitas dari pengakuan hak-hak untuk mengembangkan demokrasi yang didasari oleh kesiapan dan pengakuan pada partisiasi rakyat, dimana dalam implementasi kehidupan peran hukum strategis sebagai alat pengendalian dan pengawasan dalam masyarakat.

\section{Prospek Masyarakat Madani Indonesia}

Meski bangsa ini telah mengagendakan beberapa kabijakannya melalui agenda reformasi yang telah digulirkan beberapa tahun yang lalu, namun perubahan yang diharapkan tersebut belum bisa dirasakan secara siginifikan. Sebaliknya, perubahan destruktif justru semakin nampak di mata. Mungkin tak berlebihan bila dianggap bahwa apa yang terjadi di bangsa kita saat ini adalah keruntuhan keadaban publik (collapse of public civility) (Kompas: 2005), yang terjadi akibat adanya pendangkalan di masyarakat. Tanda-tandanya bisa terlihat dari banyaknya gejala ekstrem di masyarakat. Sebagai contoh, tingkat korupsi di Indonesia sangat esktrem sehingga negara Indonesia dimasukkan dalam kategori "terkorup di dunia", dari segi budaya bangsa Indonesia 
sudah memasuki era drunken society (masyarakat yang mabuk) dicirikan pertama, masyarakat berkeinginan keras untuk mengekspresikan kebebasannya tanpa meperdulikan kebebasan orang lain; kedua, masyarakat bertindak dan berperilaku tidak berdasarkan norma-norma yang ada; ketiga, suara-suara moral sudah tidak lagi memiliki suara kewibawaan. (Siregar, 2001: 9)

Tingkat kekerasan juga sangat ekstrem, dan ini antara lain ditunjukkan oleh serangkaian peledakan bom di gereja-geraja secara serentak di sejumlah kota di Indonesia pada malam Natal tahun 2003, juga merebaknya pertikaian antar etnis seperti di Ambon, dan Poso menandakan semakin menggejalanya konflik horisontal di Indonesia. Belum lagi tragedi peledakan bom Bali yang merengguk sekitar 200 jiwa. Demo mahasiswa yang diikuti dengan demo masyarakat ditengarai merupakan luapan ketidakpercayaan para mahasiswa dan rakyat Indonesia terhadap Negera. Emosi masyarakat juga dapat dilihat saat terjadi kerusuhan Mei 1998, dimana warga malah "bergotong royong" membakar pusat pertokoan. Bandingkan misalnya gendan penduduk kota New York yang sautu ketika dilanda pemadaman listrik total. Mereka dengan tenang bergotong royong untuk mengamankan kota dan menjalankan fungsi sosial yang terhenti. Gaya hidup masyarakat masyarakat Indonesia juga menjadi sangat ekstrem. Di tengah keterpurukan ekonomi, Indonesia tetap memiliki konsumen pembeli mobil mewah setingkat Ferrari dan Maserati.

Gejala-gejala ekstrem seperti ini hanya datang dari sebuah masyarakat yang mengalami pendangkalan pola pikir, hilangnya 
keteladanan dari sosok seorang pemimpin, dan semakin memdarnya kepercayaan masyarakat terhadap sistem sosial kemasyarakatan sehingga buta dalam melihat kompleksitas permasalahan dan bebal dalam menganalisa sisi kepentingan. Namun, optimisme tetap tak boleh hilang. Betapapun carut marutnya situasi di dalam negeri, inilah wajah Indonesia yang terus menerus berproses menemukan jati dirinya.

Disinilah peran masyarakat madani harus diberdayakan. Indonesia beruntung memiliki organisasi seperti Muhammadiyah dan Nahdlatul Ulama yang telah menjadi ujung tombak aktualisasi civil Islam (Islam kewargaan) terpenting dalam masyarakat dan bangsa Indonesia. Kedua organisasi ini telah memberikan kontribusi besar dalam menghasilkan better ordering of society (masyarakat yang lebih teratur) melalui berbagai usaha dan program dalam bidang pendidikan, keafamaan, pelayanan sosial, dan ekonomi. Muhammadiyah yang sejak awal kelahirannya mengibarkan bendera modernisme Islam memusatkan perhatian dan kegiatannya pada usaha purifikasi Islam, dakwah, pendidikan, dan usaha-usaha penyantunan sosial lainnya (Azra, 1000:146). Pandangan yang mendasar pada ayat tersebut mampu melahirkan sesuatu yang konkret, seperti sekolah-sekolah, poliklinik, panti yatim piatu, pesantren, rumah sakit, atau universitas yang terbesar dimana-mana.

Secara ringkas gagasan muhammadiyah tentang masyarakat yang unggul adalah yang memiliki tiga kualitas, yaitu: a) menegakkan yang ma'ruf; b) mencegah yang munkar; c) dan beriman kepada Allah SWT. 
Kuntowijoyo menterjemahkan tiga tema tersebut dengan istilah humanisasi, liberasi dan transendensi (Kuntowijoyo, 2001: 138)

Sedangkan NU menekanan pada kepentingan pembentukan suatu umah (persatuan umat) yang sering kita kenal dengan dokrtin "ahl alsunnah wa al-jama'ah" (Raharjo, 1999:110). Jejak ini terus ditumbuh kembangkan dan digalang kebersamaannya oleh masyarakat dalam kerangka berlomba-lomba untuk berbuat baik (fastabiq al-khairat).

Proses reformasi memang lambat dan tertatih-tatih, tetapi disadari bahwa bangsa ini telah berada pada point of no return. Jika esperimentasi sekarang ini kembali gagal, itu berarti penundaan untuk kesekian kalinya bagi pelaksanaan demokrasi di Indonesia. Mengutip komentar Nurcholis Madjid, jika merujuk pengalaman di masa lalu, dibutuhkan tenggang waktu satu generasi untuk tibanya sebuah kesempatan baru bagi eksperimen demokrasi di Negara.

Seperti telah dikemukakan di atas, masyarakat madani membutuhkan institusi sosial, non-pemerintah, yang independen yang menjadi kekuatan penyeimbang dari negara. Posisi itu dapat ditempati organisasi masyarakat, maupun organisasi sosial politik bukan pemenang pemilu, maupun kekuatan-kekuatan tertorganisir lainnya yang ada di masyarakat. Dari organisasi-organisasi terorganisir itulah diharapkan mampu membutuhkan kekuatan swadaya masyarakat.

Hegemoni kekuasaan yang sedemikian kuat sehingga kekuatan ril yang ada di masyarakat demikian terpuruk. Padahal organisasi-organisasi sosial kemasyarakatan seperti NU, Muhammadiyah ataupun LSM-LSM di Indonesia itulah yang diharapkan menjadi lokomotif untuk 
mewujudkan masyarakat madani. Menurut AS Hikam terdapat beberapa LSM yang secara konsisten memainkan peranan otonomnya akan tetapi jumlahnya belum signifikan dengan jumlah rakyat Indonesia yang selain berjumlah besar juga terfragmentasi secara struktural maupun kultural. Fragmentasi sosial dan ekonomi seperti itu sangat sulit mewujudkan masyarakat dengan visi kemandirian yang sama. Padahal utuk duduk sama rendah berdiri sama tinggi membutuhkan kesamaan visi dan kesadaran independensi yang tinggi. Dengan demikian boleh jadi masyarakat pearadaban yang kita cita-citakan masih membutuhkan proses yang panjang. Dan boleh jadi hanya impian manakala pro status quo tetap berkuasa (Hikam, 2000: 122).

Hampir semua setuju bahwa untuk menuju Indonesia yang demokratis, dibutuhkan masyarakat madani yang kuat sehingga negara tidak dibiarkan lagi menjadi penguasa wacana. Namun juga perlu diperhatikan bahwa justru rezim Soeharto tumbang, masyarakat madani mengalami proses unmaking karena buyarnya kekuatan kelas menengah yang menjadi motor gerakan ini. Sementara menurut Dawam Raharjo keberadaan kelas menengah ini adalah prasyarat demokrasi yang merupakan pilar terbentuknya masyarakat madani (kelas menengah disini yang dimaksud Dawam Raharjo adalah kelas menengah yang independen) (Raharjo, 1999: 286). Tanpa adanya keberadaan kelas menengah ini, demokrasi tidak bisa bekerja, demikian juga rontoknya kekuatan kelas menengah sebagian dikarenakan kemerosotan ekonomi. Namun, sebagian lagi dikarenakan ketidakmampuan para pemimpin sipil untuk mengkonsolidasikan kelompoknya dan membentuk kekuatan 
bersama sebagai pressure group (kelompok penekan) dalam memperjuangkan isu-isu demokrasi, penegakan hukum, pelindungan hak asasi manusia (HAM), dan penciptaan good governance.

Justru yang terjadi adalah tokoh-tokoh sipil beramai-ramai terjun ke dunia politik dengan keyakinan bahwa mereka dapat memainkan peran menentukan untuk mereformasi pemerintahan. Tetapi yang terjadi justru mereka kemudian hanyut dalam proses-proses politik yang manipulatif dan destruktif. Organisasi-organisasi kemasyarakatan yang pada awalnya berhasil melakukan political disengagement untuk menghindari diri dari kooptasi negara malah kemudian menjadi bagian dari negara itu sendiri dan terlibat dalam day to day politics.

Sebenarnya bangsa ini cukup beruntung dengan adanya fenomena baru di masyarakat modern seiring meningkatnya pendidikan dan tingkat pendapatan yaitu dengan merebaknya perkumpulan dan perhimpunan kekuatan sosial kemasyarakatan (yang kemudian lebih dikenal dengan istilah LSM). Kelompok ini (LSM) memiliki peranan yang cukup signifikan bagi pemberdayaan masyarakat kelas menengah tersebut. Dawam Raharjo (1999:293) menyebutkan bahwa ada tiga macam peranan yang bisa dijalankan oleh kelompok tersebut.

Pertama, menyaring dari menyiarkan pendapat dan rumusan kepentingan yang jika tidak dilakukan pasti tidak akan terdengar oleh pemerintah atau kalangan masyarakat umumnya. Kedua, menggairahkan dan menggerakkan upaya-upaya swadaya masyarakat daripada menggantungkan diri pada prakarsa negara. Ketiga, menciptakan forum pendidikan kewarganegaraan, menarik masyarakat untuk membentuk 
usaha bersama, dan dengan demikian mencairkan sikap menyendiri (isolatif) serta membangkitkan tanggung jawab sosial yang lebih luas.

Menurut Rasyid (1999:293) masyarakat madani di Indonesia baru berada dalam proses pertumbuhan, hal tersebut dibuktikan dengan berbagai macam faktor. Pertama adalah adanya perbaikan di sektor ekonomi, yakni semakin tinggi pendapatan masyarakat yang menyebabkan mereka tidak tergantung kepada pemerintah, bahkan secara logika justru pemerintah yang tergantung kepada masyarakat karena harus membayar pajak untuk mendukung kegiatan pemerintahan. Kedua, tumbuhnya intelektualitas. Semakin intelek suatu masyarakat, maka secara umum semakin memiliki komitmen untuk independen. Ketiga, terjadinya pergeseran budaya dari masyarakat yang berbudaya peternalistik menjadi budaya yang lebih modern dan lebih independen. Ryaas menunjuk kehadiran LSM-LSM dan lembaga-lembaga profesi sebagai wujud embrio masyarakat madani. Untuk mengembangkannya, tidak lain kecuali harus memperkuat posisi tawar-menawar (bergaining position) mereka.

Melihat fenomena dan kejadian-kejadian di atas para ahli memandang hal yang berbeda untuk pengembangan masyarakat madani Indonesia ke depan. Namun apapun dan bagaimanapun pandangan para ahli tersebut harus kita sadari bersama bahwa prospek masyarakat madani Indonesia dalam tahun-tahun mendatang kelihatannya masih belum serba pasti. Mengutip pendapat Azra bahwasannya prospek masyarakat madani Indonesia memang masih belum jelas, ada perkembangan-perkembangan yang tertentu yang menggembirakan 
kondusif, dan mendukung bagi penciptaan dan pengembangan dan indikasi tertentu yang kurang menggembirakan yang pada gilirannya dapat menjadi penghambat bagi perkembangan masyarakat madani (Azra, 1999: 5)

\section{Pendidikan Islam dalam Masyarakat Madani Indonesia}

Tantangan-tantangan yang dihadapi

Seperti diketahui bersama bahwa saat ini bangsa Indonesia sedang menghadapi wacana pembentukan masyarakat madani Indonesia. Gerakan untuk membentuk masyarakat madani tersebut berkaitan dengan proses demokratisasi yang sedang melanda dunia dewasa ini. Sudah barang tentu perwujudan kehidupan masyarakatat madani di tiap negara mempunyai ciri-ciri tertentudi samping ciri-ciri universal.

Adapun secara lebih tegas, tatanan masyarakat madani Indonesia yang dicita-citakan tersebut seperti dirumuskan oleh Malik Fajar mengandung ciri-ciri sebagai berikut: a) masyarakat madani Indonesia yang hendak diwujudkan itu adalah masyarakat beriman dan bertaqwa kepada Tuhan YME, suatu masyarakat Pancasialis yang memiliki citiacita dan harapan masa depan. Perspektif moral dan harapan itulah pada gilirannya yang akan merekatkan pluralitas dan kebhinekaan kepentingan, sehingga integritas bangsa dan negara tetap terjamin dan terpelihara; b) masyarakat madani Indnesia yang didambakan adalah masyarakat demokratis berkeadaban (democratic civility), yang menghargaiperbedaan dan keragaman pendapat dan pandangan. Bahkann perbedaanpandangan dilihat sebagai wahana dan bagian integral dari 
kehidupan berbangsa dan bernegara untuk mengembangkan kehidupan demokrasi dalam seluruh strata kehidupan; c) masyarakat madani Indonesia yang didambakan adalah masyarakat yang mengakui dan menjunjung tinggi HAM, kesetaraan, yang tidak diskriminatif dalam berbagaisegi, baik dari segi etnis, agama, gender, dan sebagainya; d) masyarakat madani Indonesia yang diinginkan adalah masyarakat yang tertib dan sadar hukum. Kepatuhan dan ketertundukan kepda hukum dan ketertiban (law and order) bahkan merupakan salah satu pilar utama dari keadaban demokratis; e) masyarakat madani Indonesia yang ingin diwujudkan adalah masyarakat baru yang merupakan bagian dari masyarakat global, yang memiliki semangat, keahlian, dan keterampilan kompetitif, namun tetap mempunyai semangat solidaritas kemanusiaan universal; f) masyarakat madani Indonesia yang hendak dibangun adalah masyarakat berkeadaban (civility) yang menjunjung tinggi nili-nili luhur yang telah mengakar dalam tatanan kehidupan masyarakat beradab dan demokratis. Nilai-nilai itu seyogyanya dapat terpelihara dari satu generasi ke generasi berikutnya; g) masyarakat madani Indonesia yang ingin diwujudkan adalah masyarakat belajar yang tumbuh dari masyarakat, oleh masyarakat, dan untuk masyarakat. Masyarakat belajar ini menempatkan pendidikan sebagai proses yang berlangung sepanjang hayat (min al-mahdi ila al-lahdi atau life long education (Azra, 2002: 19).

Melihat kondisi objektif bangsa Indonesia maka untuk membentuk masyarakat madani Indonesia menurut HAR Tilaat terdapat beberapa prinsip yang khas yang perlu diperhatikan dalam membangun 
masyarakat madani tersebut. Adapun ciri khas tersebut adalah: a) kenyataan adanya keragaman budaya Indonesia yang merupakan dasar pengembangan identitas bangsa Indonesia dan kebudayaan nasional; b) pentingnya adanya saling pengertian antara sesama anggota masyarakat; c) berkaitan dengan kedua ciri khas di atas tadi adalah toleransi yang tinggi. Dengan demikian masyarakat madani Indonesia bukanlah masyarakat yang terbentuk atau dibentuk melalui proses indokrtinasi tetapi pengetahuan akan kebhinekaan dan penghayatan terhadap adanya kebhinekaan tersebut sebagai unsur penting dalam pembangunan kebudayaan nasional; d) untuk melaksanakan nilai-nilai yang khas tersebut diperlukan suatu wadah kehidupan bersama yang diwarnai oleh adanya kepastian hukum. Tanpa kepastian hukum sifat-sifat toleransi dan saling pengertian antara sesama anggota masyarakat pasti tidak dapat diwujudkan (Tilaar, 1999:160).

Namun begitu untuk mewujudkan masyarakat madani Indonesia dengan kualitas seperti yang diharapkan tersebut di atas bukanlah hal yang mudah, semudah membalikkan telapak tangan.

Ada beberapa tantangan yang harus dihadapi berkaitan dengan kondisi bangsa Indonesia saat ini sebelum pada akhirnya sampai pada tantangan dan hambatan yang harus dihadapi diantaranya pertama pentingnya peningkatan niai tambah, kedua, perubahan struktur masyarakat, dan ketiga, persaingan global yang sangat ketat (Raharjo, 1997:60). Adapun menurut Nata (2000: 290) tantangan yang dihadapi berupa: a) suasana ketidakpastian bekepanjangan dalam tata ekonomi dunia; b) perubahan struktur masyarakat; c) sebagaimana layaknya 
bangsa yang sedang mengalami proses industrillisasi besa-besaran, masyarakat Indonesia akan terus berkembang dan bergeser dari strukturnya yang tradisionalis menuju struktur yang semakin modern; d) persaingan global yang semakin cepat; e) proses persaingan dunia yang semakin terbuka yang ditandai misalnya dengan munculnya zona perdagangan bebas, menuntut bangsa Indonesia untuk mengambil manfaat dari suasana tersebut

Selain apa yang telah disebutkan di atas berkaitan dengan tantangan yang dihadapi bangsa Indonesia H.A.R. Tilaar menambahkan bahwa kondisi keberagaman dan kemajemukan yang ada di Indonesia juga merupakan tantangan tersendiri yang harus dihadapi (Tilaar, 1999:157).

Kenyataan bahwa masyarakat bangsa Indonesia adalah suatu masyarakat yang bhineka bukan hanya karena keadaan geografisnya tetapi juga karena sejarah perkembangan bangsa Indonesia itu sendiri. Bangsa Indonesia yang majemuk dalam hal suku dengan atribut budayanya sendiri, bahas, ras, dan agama menjadi rentan konflik bilamana kita tidak mampu menyikapinya secara arif. Peristiwa-peristiwa Ketapang, Poso, atau Ambon tentu harus menjadi perhatian kita bersama.

Sementara sistem pendidikan nasional (termasuk pendidikan Islam di dalamnya) yang semula kita harapkan menjembatani untuk menghasilkan masyarakat yang beradab harus jujur diakui masih jauh dari harapan. Pendidikan kita selama ini baru sebatas penggarapan ranah kognitif belum sampai ke ranah afektif atau bahkan psikomotorik. Sehingga boleh dikatakan hasil dari upaya pendidikan yang dilalui belum 
mempunyai kulalifikasi yang memadai guna mendukung percepatan pembentukan masyarakat madani Indonesia.

Pendidikan Islam selama ini sering masih terlambat merumuskan diri untuk merepon perubahan dan kecederungan perkembangan masyarakat ktia sekarang dan masa yang akan datang. Sistem pendidikan Islam kita masih lebih cenderung mengorientasikan diri pada bidangbidang humaniora dan sosial lainnya daripada ilmu-ilmu eksak semacam fisika, kimia, biologi dan sejenisnya. Sisi lain pengembangan dan peningkatan pendidikan Islam sering bersifat sepotong-potong atau tidak komprehensif. Sistem pendidikan Islam tetap lebih cenderung berorientasi ke masa silam daripada ke masa depan (Azra, 2000: 59). Itulah beberapa tantangan yang harus dihadapi bangsa ini dalam menuju terbentuknya masyarakat madani Indonesia.

\section{Pendidikan Islam sebagai Cerminan Masyarakat Madani Indonesia}

Sebagaimana telah diketahui dan diyakini bersama, Islam adalah agama yang sempurna, Islam dalam realitas sosialnya bermakna ganda, satu sisi sebagai agama yang diwahyukan, dan pada sisi yang lain agama sepanjang pemikiran dan pemahaman pemeluknya. Sebagai agama yang diwahyukan Islam merupakan petunjuk Allah bagi manusia untuk mengelola kehidupannya. Termasuk di dalamnya cara pengelolaan hubungan manusia dengan dirinya sendiri, alam jagad raya, dan dengan Allah SWT yang menciptakan. Sedangkan Islam dalam konteks keindonesiaan, sebagai agama yang mapan diharapkan mampu 
memberikan kontribusi yang paling banyak untuk memenuhi kebutuhan bangsa dengan sistem nilai-nilai yang kuat (Madjid, 1998: 122).

Hakekat Pendidikan Islam merupakan proses transformasi ajaran dan nilai-nilai Islam yang berfungsi sebagai rahmatan lil 'alamin. Dalam persepektif inilah yang pada akhirnya pendidikan Islam penulis anggap memiliki potensi besar dalam kerangka membentuk masyarakat madani Indonesia.

Menyimak beberapa karakteristik masyarakat madani Indonesia sebagaimana yang telah dipaparkan dalam bab sebelumnya, maka pendidikan Islam dalam kapasitasnya sebagai bimbingan jasmani dan rohani peserta didik merupakan cermin menuju masyarakat madani Indonesia haruslah bernuansa: free public sphere, demokratis, toleran, pluralisme (Majdid, 2000 : 25), dan keadilan Sosial (Rosyada, 2003:250).

Mengkaji hal-hal yang telah disebutkan di atas, model pembiasaan-pembiasaan peserta didik dalam lingkungan pendidikan sangat berpengaruh terhagap pembentukan sikap kesehariannya. Lingkungan pendidikan dipandang merupakan wadah pendewasaan diri dalam kerangka membentuk nilai-nilai keadaban yang diperlukan dalam kehidupan bermasyarakat, berbangsa, dan bernegara sehingga pembentukan sikap dan watak (karakter) tidak boleh dikesampingkan begitu saja. Bermula dari individu-individu yang tersadarkan itulah pada akhirnya akan terbangun suatu tatanan kehidupan masyarakat madaniyah yang dicita-citakan. 


\section{Simpulan}

Dari berbagai diskripsi yang telah penulis sampaikan di atas, dalam kaitannya dengan Pendidikan Islam dalam Masyarakat Madani Indonesia, maka akhirnya dapat disimpulkan sebagai berikut:

Sebagaimana telah kita ketahui bersama, mayoritas bangsa Indonesia adalah umat Islam. Kenyataan ini membawa implikasi yang tidak dapat disanggah lagi bahwa masa depan umat Islam Indonesia akan sangat menentukan arah perjalanan bangsa Indonesia ke depan. Masyarakat madani di sini tidak lagi diperhadapkan secara oposisional dengan negara (oposisional state), melainkan merupakan sisi lain dari koin yang sama (sisi satunya adalah negara).

Masyarakat madani Indonesia mengacu kepada konsep masyarakat madaniyah yang dikembangkan oleh Rasulullah, yakni masyarakat yang memiliki keadaban demokrasi, bertakwa kepada Allah SWT, yang seimbang antara dimensi fikir (iptek) dan dimensi dzikir (imtaq), dan mampu menyelaraskan dimensi abdun, sebagai makhluk Allah yang tanpa daya dan dimensi khalifah, sebagai pemimpin di muka bumi. Sehingga melahirkan sosok manusia yang dalam istilah al-Quran disebut sebagai ulul albab. Berangkat dari terbentuknya pribadi-pribadi yang tersebut maka akan terbentuk sebuah komunitas yang dikenal dengan masyarakat madani Indonesia.

\section{Daftar Pustaka}


Hikam, As. Muhammad. 2003. Islam, Demokratisasi dan Pemberdayaan Civil Society. Jakarta: Erlangga.

Arikunto, Suharsimi. 1980. Prosedur Penelitian: Suatu Pendekatan Praktek. Jakarta: Bina Usaha.

Azra, Azyumardi. 1999. Menuju Masyarakat Madani, Gagasan, Fakta, dan Tantangan. Bandung: PT. Remaja Rosdakarya.

Bakker, Anton dan Zubair, Achmad Charris. 1990. Metodologi Penelitian Filsafat. Yogyakarta: Kanisius.

Busyairi, Ahmad dan Azharuddin Sahil, ed. 1987. Tantangan Pendidikan Islam. Yogyakarta: LPM UII.

Harris, Misbah Shoim. 1987. Doktrin Wong Cilik (Pergulatan Islam dalam Realitas). Yogyakarta: Azzura.

Kuntowijoyo. 2001. Mulsim Tanpa Masjid : Esai-Esai Agama, Budaya, dan Politik dalam Bingkai Struktualisme Transendental. Bandung: Mizan.

Madjid, Nurcholis. 2000. Masyarakat Religius. Jakarta: Paramadina.

Nata, Abuddin. 2000. Akhlak Tasawuf. Jakarta: PT Raja Grafindo Persada.

Raharjo, Dawam. 1999. Masyarakat Madani: Agama, Kelas Menengah dan Perubahan Sosial. Jakarta: LP3ES.

Rosyada, Dede, et al. 2003. Pendidikan Kewargaan (Civic Education), Demokrasi, Hak Asasi Manusia dan Masyarakat Madani. Jakarta: ICCE UIN Syarif Hidayatullah dan Prenada Media.

Subagyo, Joko. 1991. Metode Penelitian dan Praktek. Jakarta: Rhineka Cipta.

Saukah, Ali. 2000. Pedoman Penulisan Karya Ilmiah. Malang: IKIP Malang.

Stempel, Guide H. 1983. Content Analysis, terj. Jalaludin Rahmat dan Arko Kasta. Bandung: Arai Komunikasi.

Tilaar, H.A.R. 1999. Pendidikan, Kebudayaan dan Masyarakat Madani Indonesia, Strategi Reformasi Pendidikan Nasional. Bandung: PT. Remaja Rosdakarya.

http://www.hidayatullah.com/berita/nasional/read/2010/10/03/44994/piag am-madinah-harus-jadi-acuan-masyarakat-madani. html: Piagam Madinah Harus Jadi Acuan Masyarakat Madani 
Mudarrisa: Jurnal Kajian Pendidikan Islam, Vol. 7, No. 2, Desember 2015: 229-258 